Assuming that the red spots period of rotation is $9^{\prime \prime}$ $55^{\prime \prime \prime} 37^{\circ} .065^{-}$-which is probably very near the truth-we find that in one minute of time 0 ".6o+ of the surface will pass a given meridian. Multiplying the minutes in the last, or column 7 : by .604 , we get the following table of lengths in longitude on the surface of Jupiter. The first nine are takien from a table of eleven transits observed by me previous t.) August 30, and published in linslish . Michanii, No. Son:

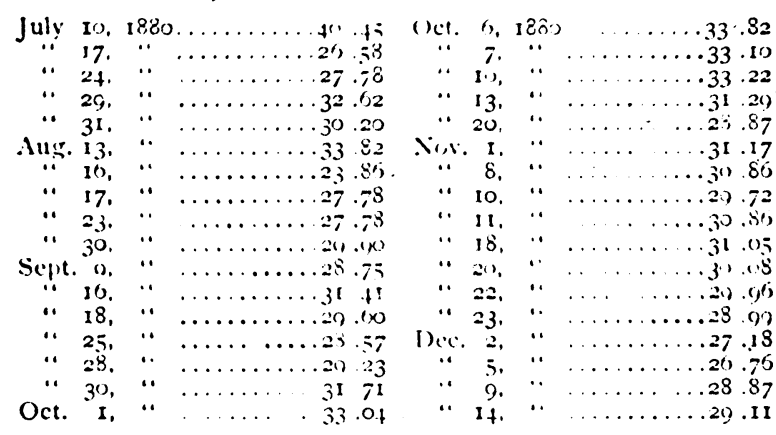

On July to the spot hall a narrow strip runining from its preceding end. To this is clue the great length of the spot on that date. This does not indicate the true lengih of the spot proper, but as it was a porticn of the spo: or continuation, I give the length on that date.

It must not be supposed that, because I have carried the lengths to two places in the decimals, 1 consider the length accurate to that degres, for the observations have been entirely eye estimations, yet they were very carefully made. I think a variation of one degree in the length of the spot would be casily detected, and probably a less amount, as the arrecment between most of the ficures is too close and regular to attribute to chance. As my methed of observing may be of interest. I will give in example from my mote bonk. Birst: I watch closely the first end of the spote and imagne a line drep)ped from it to the equatorial b:le and ofiserve when this is central, for it is much casier to halre the straight edgelike line of the equatorial belt than to halle the disk on a parallel with the spots centre, because the spol itself heing $(n$ one sicle of the meridian biases our judgment to a certain extent, while the clean edere of the cquatorial belt is free of any obstacle to intertere with our judgment. Second: I compare the spaces between the limbs of the planet and the ends of the spot, when these are seen to be erpual, of course the spots centre is in transit. For determuning the transit of the following end, the same method as that in deferminirg the preceding end is followed. It the observation of each part of the spot there exists for a short while a perind of uncertainty. 'The beginning of this uncertainty' I indicate by " noting the time. In a minute or su I feel sure the time of true phase has arrivel, this is noied by $t$, with its time. Shortly, I am certain the phase has passed, this I $n$ te as c. with its lime. The mean of the three is tatien for the erue phase.

The following is an observation sf the transit of the

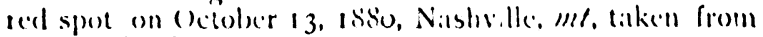
my n te bork.

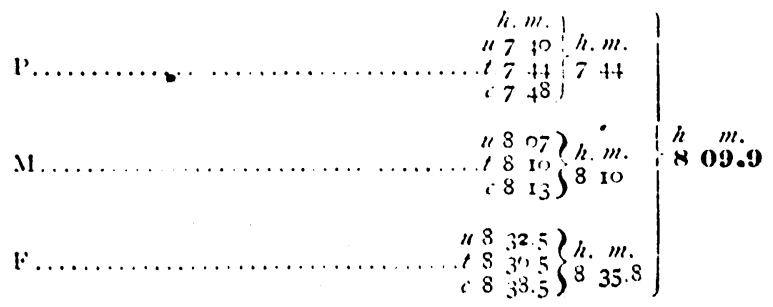

The mean of the nine observations agrees with the observed middle transit to . $\mathrm{m}$. This close agree. ment cannot, of course, be expected often. However, they generally agree to within a few fractions of a minute. In no case have I allowed myself to know beforehand what time any phase should occur, as this might influence the observations.

The variations in length of the spot are not only shown by the duration of transit. but are sensibie to an observiner eye. At each observation I estimate its length, comparing it with the brexdth of the disk on the same parallel of latitude. These comparisons show changes in its length, as they vary from $1-3.5$ to $1 / 3$ the breadth of the disk, but it is grenerally the slirrhtest bit less than one-third.

The variations in breadth are compared with the great equatorial band, but unfortunately this is a standaril that probibly varies itself. The spot's breadth is generally slightly less than "2 the width of the equaturial belt, sometimes it is probably fully half as broad as the bett, but 1 have never seen it broater then that.

Changes in the width of the space between the south edge of the equatorial $b: 1$ and the nor:h edge of the spot, are more readily detected, as the space can be easily compared with the breadth of the spor. This space is enenerally equal to $1 / 3$ the spot's brealth, yet it is sometimes nearly ont-halt as broad as the spot. I have seen it diminished to one-sisth. These changes are due either to a swelling out of the spot or a broadening of the equatorial belt. It is more likely due to changes in the spot. I have on several occasions estimated that the distance between the southern edire of the equatural band and the southern edge of the spot was about cqual to cne-third the distance from the south pole to the equatorial belt.

There are sometimes slight changes in the general form of the spat; at times the ends are blunt or rounded, again they are cigar shared. One end has been seen rounded while the other was very much pointed. The sicles are at times a little Hatlened, but are generalle slightly rounded. (1) July if the south-side was curved or conves, while the norti-side was somewhat thattened. It is sometimes long and lanky and then agin it is tat and "chubby"-neither of these have been carried to extremes. Faint continuations, or trails, have been visible, sometimes from one end and then from the other. These have on several occasions been seen trailing from both ends at once, but are not always seen without close looking. At times the spot is a deep solid brick color; then again it is lightish red and pale. I have never, for certain, seen any detail on the surface of the spot, but I have sometimes thought that there ia'zs detail but just too incletinite for my aperture. The outline of the spot is always clean--no diffusion.

These observatiuns ite frum notes and stetches which I have made this year with a 5 -inch Byrne refractor.

N.ssuvitu, Tr:xi., Decimbir 27, 1830. E. L. BakNals.

Nork.--The motions of the spots on Jupiter, in an article by me in "Scllixes:" No. 24, are referred to an assumed rotation period of oh. $55 \mathrm{~m}$. $27.08 \mathrm{~s}$.. which should have been stated in that article. $\quad$ E. l.. B.

\section{PENNULE'S COMET.}

The following position of this comet was obtained by ring micrometer, on December $30,1850,7$ h. $01.2 \mathrm{~m}$., Nashville m. t.:

$$
\begin{aligned}
& \text { R. A. } 19 \text { h. } 55 \mathrm{~m} \cdot 3^{8.5 \mathrm{~s}} \\
& \text { 1)ec. }+18 \\
& 52
\end{aligned}
$$

It is several minutes in diameter and very brightly condensed.

NAsiville, Tenn., Jan, 2, '8r. 


\section{THE CAMBRIDGE OBSERVATORY.}

The Annual Report of Prof. Pickering, Director of Harvard College Onservatory, shows that the Observiltory has been in a most prosperous condition during the pas: year, and if the same financial support is ex'ended to it in the future that has been so generously offered in the pilst lew yeatrs, it will be enabled to retian its place, inferior to no other Obiervillory in the country. Ihe work carried on at the combridge () oservittury consists of observations with the $15 \mathrm{in}$. Liguntorial, with the Meridian Circle and Meridian Photulaster, together with the altendant reductions; and in the distribution of timesignals over the greater part of New England.

With the large equatorial, many important observations upon the satellites of Mars were macle during the opposition of that planet. Empluying the methud of reducing the light of the planet, by colored glass (a method tirst used at this (Ol)serviatury). the number of observed position angles of l leimos was 825 ; of lhobos, 278 ; and ihat of observed distinces, 248 . The probable error's of o.e setting were respectively $0.6^{\prime}, 0.9^{\prime}$ and $0.6^{\prime \prime}$. Besides the micrometric work, many photometric observations were made, the results of which indicate that it Ne assume the satellites to have a capacity for reflecting sunlight equal to that of Mars itself, Deimos has a diameter of about six, and l'nobos of about seven miles. The photometric observattions upon the eclipses of Jupiter's satcllites grive reatson to belicere that by this medhod the determination of longitules maly be matele ats atceurately as hy occultattons or funar culminations. Me:asurements of the light of planctary nebulat halle been continued. The: spectrit of nebulie are also observed through a direct vision prism placed b:tween the object glass and eyepiece of the telescope. The planetary nebulite retiun their shape under these circumstances, obriously indicating that their light is monochromatic. The difference between monochromatic objects and ordinary stars is so marked when thus examined, that a method of detecting smill nebulae was at once suggrested, and a comparatively short search revelled three such objects. The nost remarkable discovers, however, wis in the spectrum of the star ()eltoen 17681, R.... 18h. $1 \mathrm{~m}$. 17s., Dec. $-21^{\prime} I^{\prime}$, which show's that the light is concentrated in two points of the spectrum, one in the blue, the other in the yellow. I fitint, contmuous sp::ctrum is also sech.

Between Sipt. 24, 1879 an.1 No1. 1, 1880 , observations were mate with ihe Mericlian Circle on 277 diss, the work being confined to the determination of the absolute

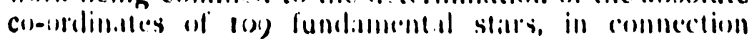

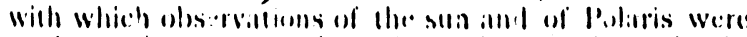

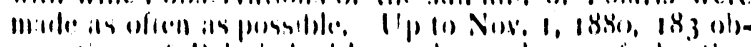

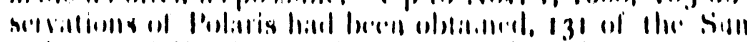

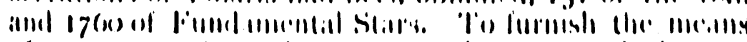

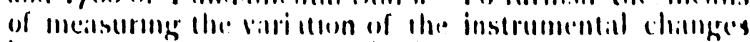
between one culminatton of Poliris and the next, a collimbtur with fexal lengith of zor feet was constructed and has given excellent results.

.1 Meridian Photomeder devised by Prof, Packering has been used in continuing the measurement of the light of all stars visible to the naked eye between the north pole and the parallel of $30^{\circ}$ south declination. () ver 40.000 separate settings hate already been made, and it is probable that the work will be completed in ()etober next. The instrument, as its name implies, is mounted in the nereiction and forms polarized manges of the pole star and the st:ar to be observed, which ate brought to (epuality by lurning a Nicol prism.

The time slenals fiom the (observatory are distributed to the railroads and several prominent jewelers in Bus'on, and through the railroal companies to many of the neighboring towns. By the co-operation of the United

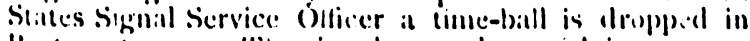
Beston all noun. Ihe signals alle also usiel in cunnection with thuse from the United States Naval Observa- tory, and the Allegheny City Observatory for the regulation of the New York time service.

During the past year, the second part of Volume XI of the Annals of the Observatory, containing a discussion of $25,00 \mathrm{~J}$ photometric observations made with the great equatorial, and Volume XII containing the results of obscirvittions matle by l'rof. W. $A$. Rogers in 1874 and 1875 with the Meridian Circle have heen completed and distributed, and six more: volumes are in a more or less advanced state of preparation.

WAsillis(itos, D. C.

\section{ON THE THERMAL BALANCE.* \\ BY PROF. S. P. I.ANGI.kY.}

When the thermometer is not sufficiently sensitive for delicate investigation of radiant heat, scientific men have been accustomed, since the time of Melloni, to the use of the thermopile, an instrument which, emplojed in commection with the gialvanometor, permits the making of numerous important meitsures. It has not been improved materially in the last fifty jears. Meanwhile, many problems of both high theoretical and prictical interest have arisen, which cannot be soliet without a more sensitive and accurate instrument. (ne of these problems is the measurement of the distribut on of radiant energy in a pure spectrum, when the rays have not passed throngh any prism. I could obtain no atceurate results with the themopile. I wats forced to incent a more sensitive instrumedet for this special inve'stigattion, and, hatring clome so, I believe it will be of general utility: The principle of the new appoaratus hats hecen appliced by Dr. Sicmens and others (1) other purposes. I spent sceveral months in making it, as I hopre, a useful working tool for the physicist and the p'ysical astronomere. It is founcled on the principle that, if a wire cunveying an eleceric current be heated, less electricity flulls through it than before. If two şlich wires, carrying equal currents from a powerful battery, meet in a recording apparatus (the galvanometer) the index of the instrument-pushed in two opposite ways by exactly equal toree;-will remain at rest. If one current be diminished by warming ever so little the wire that conveys it, the other current causes the inclex to swirg with a force llue, not directly to the fecble he:at which warmed the wire, but to the power of the: bittery winch this fechle heat controls.

The application of this principle is thus made: Iro: or steel is tolled into sheets of extreane thinness. I have succereded in rolling sheets of stecel marle at the works of

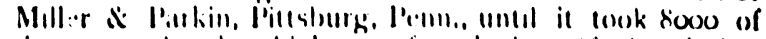

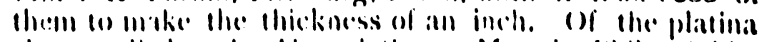

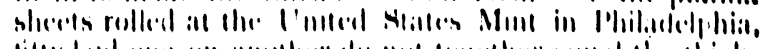

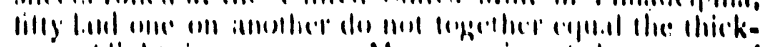

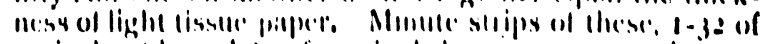
ill inch wisle and 't of ill inchl long. Were minted so as (1) form a prominnent port of the circuit, throwgh which a patrt of a pewerful ballery passed to the galliansometer. fixperiment proses that an almost inconcellably minute warming of it set of these strips reduced the pissinge of the electricity so as to produce very larere indications on the registering instrument. I hale in the course of my
experiments thus far, found iron the most adrantageous, though other metals are still under trial. The instrument thus formed is from ten to thirty times more sensitive than the most delicate thermopile; but this is almost a secondary allantage compared with its great precision and the readiness with which it is used. The thermopile is very slow in its action. This new instrument, the thermal-balance, takes up the heat anct parts with it again in a single second. It is almost as prompt as the human eje itself.

With reference, to its accuracy, experiments prove thit the probible error of a single meissurement miale

- Kead lecfore the Nativanal Acil lemy of sciences, N. Y., 1880 